ECOLOGICA, Vol. 28, No 104 (2021), 625-633

https://doi.org/10.18485/ecologica.2021.28.104.19

Originalni naučni rad

UDC: $342.7(4-67 \mathrm{EU})$

$341.018(4-67 \mathrm{EU})$

\title{
Povelja EU o osnovnim pravima i pravo na (zdravu) životnu sredinu
}

\section{EU charter of fundamental rights and the right to a (healthy) environment}

\author{
Dragoljub Todić \\ Institut za međunarodnu politiku i privredu, Makedonska 25, Beograd, Srbija / \\ Institute of International Politics and Economics, Makedonska 25, Belgrade, Serbia \\ orcid.org/0000-0002-3813-4608, e-mail: dtodic@ymail.com \\ Rad primljen / Received: 02.08.2021, Rad prihvaćen / Accepted: 09.11.2021.
}

Sažetak: U radu se razmatra pitanje odnosa Povelje EU o osnovnim pravima (Povelja) prema pravu na (zdravu) životnu sredinu. Prvi deo rada sadrži analizu odredaba Povelje koje se odnose na životnu sredinu i koje su od značaja za životnu sredinu. Drugi deo rada je posvećen pitanju odnosa Povelje prema međunarodnim ugovorima. Odvojeno se ukazuje na međunarodne ugovore u oblasti životne sredine i međunarodne ugovore $u$ oblasti ljudskih prava. $U$ tom smislu ukazue se na međunarodne ugovore $u$ oblasti životne sredine u kojima je EU članica i daje se osvrt na odnos ovih međunarodnih ugovora prema pravu na (zdravu) životnu sredinu. Takođe, ukazuje se na relevantne odredbe Evropske konvencije o osnovnim pravima i slobodama koje obavezuju države članice EU. U trećem delu rada se daje pregled ustavnih odredbi država članica EU koje formulišu pravo na (zdravu) životnu sredinu. Razmatra se stav da sadržaj i domete odredabe Povelje treba tumačiti u širem kontekstu, vodeći računa o međunarodno-pravnom obavezama i ustavnim odredbama država članica o životnoj sredini. U zaključku se konstatuje da pravo na (zdravu) životnu sredinu, iako nije eksplicitno formulisano u Povelji, ima svoje utemeljenje u relevantnim izvorima prava od značaja za pravni sistem EU i država članica.

Ključne reči: pravo na (zdravu) životnu sredinu, ljudska prava, životna sredina, Evropska unija, međunarodno pravo, pravo EU.

\begin{abstract}
The paper discusses the relationship between the EU Charter of Fundamental Rights (Charter) and the right to a (healthy) environment. The first part of the paper contains an analysis of the provisions of the Charter that relate to the environment and that are of relevance for the environment. The second part of the paper is dedicated to the relationship of the Charter with international agreements. International environmental agreements and international human rights agreements are discussed separately. In that sense, the paper points to international environmental agreements the EU is a member of and provides an overview of the approach of these international agreements to the right to a (healthy) environment. It also points to the relevant provisions of the European Convention for the Protection of Human Rights and Fundamental Freedoms, which are binding on EU Member States. The third part of the paper provides an overview of the constitutional provisions of the EU Member States that contain provisions on the right to a (healthy) environment. The view is considered that the content and scope of the provisions of the Charter should be interpreted in a broader context, taking into account the international legal obligations and EU Member States' constitutional provisions on the environment. In conclusion, it is stated that the right to a (healthy) environment, although not explicitly formulated in the EU Charter, has its foundation in sources of law relevant to the legal system of the EU and Member States.
\end{abstract}

Keywords: right to a (healthy) environment, human rights, environment, European Union, international law, EU law. 
1. EU POVELJA O OSNOVNIM PRAVIMA I

ŽIVOTNA SREDINA /

EU CHARTER OF FUNDAMENTAL RIGHTS AND ENVIRONMENT

1) Osnovni predmet istraživanja u ovom radu je pitanje odnosa Povelje EU o osnovnim pravima (Povelja) prema pravu na (zdravu) životnu sredinu. Za osnovu analize se uzimaju odredbe člana 37 . Povelje, koje se neposredno odnose na životnu sredinu, kao i druge odredbe koje mogu biti od značaja za sagledavanje postojanja i domašaja prava na (zdravu) životnu sredinu. $U$ tom smislu se, pored Povelje, posebno sagledavaju relevantne norme međunarodnog prava na koje upućuje Povelja, kao i ustavnog prava država članica EU. Cilj rada je utvrđivanje postojanja prava na (zdravu) životnu sredinu u pravnom sistemu EU. Koristeći dogmatički metod radi utvrđivanja konkretnog značenja pojedinih pravnih normi sadržanih u Povelji, kao i normativni, kako bi se razumeo smisao ideja iz Povelje u kontekstu celovitog normativnog sistema EU, istražuju se veze između prava EU, međunarodnog prava i ustavnog prava. Komparativnim metodom se ispituju ustavne odredbe država članica EU, s ciljem utvrđivanja sličnosti i razlika u normama država članica EU u pogledu njihovog odnosa prema pravu na (zdravu) životnu sredinu.

2) Evropska unija (EU) je svoj poseban dokument o ljudskim pravima, Povelju o osnovnim pravima (Povelja), dobila krajem prošlog veka da bi stupanjem na snagu Lisabonskog ugovora (2009) Povelja postala i pravno obavezujuća (EU, 2007; $\mathrm{MEI}, 2021)$. Dokument ima istu pravnu snagu kao ugovori EU (Etinski, 2008; Đorđević, 2011), i prema članu 52. stav 2 ,prava koja priznaje ova povelja, a koja su predviđena Ugovorima, ostvaruju se pod uslovima i u granicama utvrđenim tim Ugovorima". A „svako ograničenje ostvarivanja prava i sloboda priznatih ovom poveljom mora biti predviđeno zakonom i poštovati suštinu tih prava i sloboda. Uz poštovanje načela proporcionalnosti, ograničenja su dopuštena samo ako su neophodna i zaista zadovoljavaju ciljeve od opšteg interesa koje priznaje Unija ili potrebu da se zaštite prava i slobode drugih" (čl. 52. stav 1). Za šire videti: Dawson, i dr. 2019). Postoji više pitanja koja se mogu smatrati otvorenim zbog čega pitanje karaktera i sadržaja normi iz Povelje zaokuplja pažnju stručne javnosti. Nešto više od jedne decenije nakon stupanja na snagu, pojavili su se i predlozi za izmene i dopune Povelje koji se temelje na različitim argumentima (Klinger, 2021; Dawson, 2020; Magalhães, 2018).

Značaj i domete Povelje u delu koji se odnosi na životnu sredinu mogu se procenjivati na nekoliko načina. Obično se početnim korakom smatra sagle- davanje sadržaja i implikacija člana 37. koji glasi: „Visok nivo zaštite životne sredine i poboljšanje kvaliteta životne sredine moraju biti integrisani u politike Unije i obezbeđeni u skladu sa načelom održivog razvoja". Iz ovakve formulacije člana 37 , najmanje tri elementa se mogu relativno jednostavno razaznati. Najpre, cilj koji se sastoji u „visokom nivou zaštite životne sredine i poboljšanju kvaliteta“, zatim, zahtev da takvi ciljevi „moraju biti integrisani u politike Unije“, i na kraju, obaveza poštovanja „načela održivog razvoja“. Istovremeno, odmah je uočljivo da ovakva formulacija člana 37 . iz Povelje jasno podseća na nekoliko odredbi iz drugih dokumenata EU. Zbog toga izgleda da bi se moglo tvrditi da su u pravu neki autori kada naglašavaju činjenicu da član 37. Povelje ustvari ne bi trebalo tumačiti šire od onoga što već sadrže član 3. stav 3 . Ugovora o EU i član 11. Ugovora o funkcionisanju EU (MarinDuran i dr, 2013, p. 7).

Ipak, potreba preispitivanja značaja člana 37 , a posebno priznavanje postojanja, tumačenje i primene prava na (zdravu) životnu sredinu ima više dimenzija. Tome doprinosi nejasan karakter normi iz člana 37. Povelje. De Sadeleer (2012, p. 43) konstatuje da su, za razliku od većine drugih odredbi Povelje, članovi 35, 37 i 38. Povelje (odredbe posvećene zaštiti životne sredine, zaštiti potrošača i zdravstvenoj zaštiti) formulisani kao izjave o politici, a ne kao individualna prava. Nije ni čudo što se do sada relativno skromna pažnja posvećivala njihovom pravnom statusu. $S$ druge strane, značaju rasprave o ljudskim pravima u oblasti životne sredine doprinosi i rastući značaj problema u oblasti životne sredine (ili percepcija dela javnosti o tome). Ljudska prava postaju oblast koja sve naglašenije prožima sve veći broj pitanja od značaja za savremeni život, uključujući $\mathrm{i}$ probleme u oblasti životne sredine. Otuda i značaj ove rasprave za Republiku Srbiju (RS), a domete Povelje treba posmatrati i u kontekstu ukupnih aktivnosti RS na planu usaglašavanja unutrašnjih propisa sa propisima EU i pridruživanja sa EU (Vukasović i dr, 2021, p. 146).

3) Literatura u kojoj se pravo čoveka na (zdravu) životnu sredinu sve intenzivnije sagledava obiluje različitim argumentima u prilog formulisanja ili prihvatanja stava o postajanju ovog prava (kao ljudskog prava), ili protiv toga. Ovo, naročito imajući u vidu da se Povelja EU direktno određuje spram međunarodnih ugovora u oblasti ljudskih prava. Feliziani (2012, p. 543) smatra da je iz nekoliko „međusobno povezanih" razloga moguće govoriti da je pravo na (čistu i zdravu) životnu sredinu utemeljeno u pravnom sistemu EU, bez obzira na činjenicu što Povelja eksplicitno ne govori o pravu na zdravu životnu sredinu. Prvo, na zakonodavnom nivou, 
evropske mere koje se odnose na životnu sredinu često kao svoje ciljeve navode i zaštitu zdravlja, kao što je to slučaj u nekim direktivama. Na „zdravlje“, kao predmet zaštite, upućuju i međunarodni ugovori u oblasti životne sredine. Osim toga, koncept održivog razvoja, koji je uveo Amsterdamski ugovor 1999. godine, predstavlja jedno od najvažnijih načela politike EU u oblasti životne sredine, posebno u pogledu garantovanja zaštite budućih generacija. Autor ukazuje i na činjenicu da sudije sve više priznaju pravo na zaštitu od zagađivanja, a dužnost država da izbegavaju takve štetne situacije za životnu sredinu i zdravlje ljudi sugeriše postojanje odgovarajućeg prava. Fokusirajući se na pitanje načina kako to pravo može da se učini efikasnim, u razvoju prava su jasno profilisana tri proceduralna prava (pravo na pristup informacijama, pravo na učešće u odlučivanju u pitanjima koja se tiču životne sredine i pravo pristupa sudovima, odnosno pravo na pravnu zaštitu prava u oblasti životne sredine (Feliziani, 2012, p. 544). Dogaru (2014) postojanje prava na zdravu životnu sredinu izvodi iz ekstenzivnog tumačenja i primene drugih prava koje Evropska konvencija o ljudskim pravima garantuje.

Ispitivanje dometa člana 37. Povelje uslovljeno je i širim kontekstom odnosa između obaveza iz Povelje i obaveza koje proističu iz međunarodnih ugovora u oblasti životne sredine. lako pitanje veza sa pravom na (zdravu) životnu sredinu kao ljudskim pravom na prvi pogled ostaje sporno, nekoliko je pitanja koje bi u detaljnijoj raspravi trebalo imati u vidu. Najpre, trebalo bi razjasnisti opšte pitanje mesta koje pravo na (zdravu) životnu sredinu ima u sistemu međunarodnih ljudskih prava. Odnos između ljudskih prava i prava na zdravu životnu sredinu razmatra se iz različitih perspektiva. Neki autori govore o najmanje tri glavne škole mišljenja. Jedna koji podržava stajalište da nema ljudskih prava bez prava na životnu sredinu, drugi koji to pravo vidi spornim i na kraju mišljenja kojima se priznaje postojanje pravo na zdravu životnu sredine, ali se njegovo postojanje izvodi iz drugih ljudskih prava, kao što su pravo na život, pravo na zdravlje i pravo na informacije (Giorgetta, 2002, p. 175). Obim i svrha prava na (zdravu) životnu sredinu i dalje su predmet rasprava. „Postojeći međunarodni konsenzus podrazumeva zaštitu životne sredine za dobrobit ljudi. To je zato što se ideja prava gradi oko vlasničkih prava, što podrazumeva odnos superiornosti između ljudi i neljudi, kao i prisvajanje prirode“ (Borras, 2016, p. 128, 129). Posledica ovakvog pristupa je da su vrednosti u životnoj sredini zaštićene ne zato što imaju vlastitu unutrašnju vrednost, već zbog svoje uloge u zadovoljavanju ljudskih potreba. Ljudi bi stoga trebali odlučiti o potrebnom stepenu zaštite. Ova je formulacija logična posledica tradicionalnog koncepta ljudskih prava. Uopšteno, pravni sistemi imaju svojstvenu antropocentričnost i većina in zanemaruje trenutni društveni impuls koji zagovara zaštitu zdrave životne sredine „same za sebe“. Sledom toga, Borras $(2016$, p. 128, 129) smatra da, uprokos činjenici da je ljudsko pravo na životnu sredinu ima neku vrstu društvene potvrde, njegov odnos s drugim pravima i zaštitom životne sredine još uvek nije zagarantovan ni sadašnjim ni budućim generacijama.

Ali, ostaje nejasno kome je usmerena (namenjena) ovakva odredba člana 37 . Naime, u relevantnoj odredbi člana 37. formulišu se, pre svega, određene dužnosti (obaveze, ciljevi) nadležnih subjekata u vezi sa životnom sredinom. Ako se pogleda član 51. Povelje onda se jasno vidi da je propisano i kome su odredbe povelje "upućene“. To su „organi, tela, službe i agencije Unije, uz uvažavanje načela supsidijarnosti, a državama članicama samo onda kada sprovode pravo Unije. Oni stoga poštuju prava i načela i podstiču njihovu primenu u skladu sa svojim ovlašćenjima i uz poštovanje granica ovlašćenja koja su Ugovorima poverena Uniji“. U nastavku se pravi jasna naznaka u pogledu toga da „Povelja ne proširuje oblast primene prava Unije izvan ovlašćenja Unije, ne uspostavlja nova ovlašćenja ili zadatke za Uniju, niti menja ovlašćenja i zadatke koji su utvrđeni u Ugovorima“. Opisano stanje otvara nekoliko pitanja među kojima su i pitanja da li to znači da se Povelja EU i ne bavi pravom na (zdravu) životnu sredinu, kao ljudskim pravom, i kakvi bi mogli biti dometi takve situacije. To nas, najpre, upućuje na potrebu preispitivanja karaktera Povelje EU kao dokumenta, sadržaja prava koje ovaj dokument reguliše i njihovih međusobnih odnosa, zatim uvažavanja specifičnosti prava EU u oblasti životne sredine kao grane prava, njenog odnosa sa drugim srodnim granama, kao i sudske prakse. Naravno, u široj analizi bi trebalo uzeti u obzir i praksu država članica EU u vezi sa odnosom prema pravu na (zdravu) životnu sredinu. Međutim, trebalo bi imati u vidu da bi pitanje kvalifikacije (opisa) životne sredine o kojoj raspravljamo moglo biti predmet posebne analize. Zbog ograničenog prostora ovde se ne upuštamo u dalju raspravu o tome, iako bi trebalo imati u vidu da se pojavljuju različite formulacije. Pored „zdrave“ životne sredine, neki propisi, dokumenti i autori naglašavaju druge osobine životne sredine koje se kao ljudska prava garantuju (ili bi trebalo da se garantuju). Npr. „povoljna“ životna sredina, „adekvatna“ životna sredina, „prijatna“ životna sredina, „zadovoljavajuća“ životna sredina, itd. U Izveštaju specijalnog izvestioca UN koriste se sledeće formulacije: sigurna, čista, zdrava i održiva 
životna sredina (UN, 2019). Ovome bi trebalo dodati i činjenicu da se danas sve češće govori i o ljudskim pravima koja se vezuju za pojedine segmente životne sredine, a ne samo životnu sredinu kao celinu. Tako se, na primer, raspravlja o pravu na (zdrav ili čist) vazduh (Misonne, 2021), pravu na (stabilnu) klimu (Bell, 2013), pravu na vodu (Vučić, 2017), itd. Osim toga, šira analiza bi morala imati u vidu i odnos prema ljudskim pravima u državama članicama EU, odnosno funkcionisanje pravnih i političih sistema država članica. Takođe, za oblast životne sredine izuzetno su značajna i pitanja eksploatacije i prava vlasništva nad prirodnim resursima. Ustavi većeg broja država sadrže i odredbe koje se odnose na ova pitanja. Pored toga, načelno pitanje odnosa prema međunarodnom pravu, koje sadrže pojedini ustavi, može biti izuzetno značajno za pitanja zaštite životne sredine naročito u kontekstu odnosa prema međunarodnim obavezama u ovoj oblasti. To podrazumeva da bi, pored ustava, kao najviših pravnih akata država članica, u detaljnijoj analizi trebalo uključiti sagledavanje stanja u posebnim zakonima i podzakonskim aktima kojima se uređuju pojedina pitanja od značaja za oblast životne sredine.

4) Metodološki posmatrano, za sagledavanje domašaja prava i obaveza koji proističu iz člana 37. Povelje neophodno je imati u vidu i pitanje odnosa člana 37. sa drugim odredbama Povelje. A u raspravi o odnosu člana 37. sa drugim odredbama iz ovog dokumenta najpre bi trebalo konstatovati da je odredba ovog člana smeštena u IV Naslov („Solidarnost") i da se u okviru ovog naslova nalazi još jedanaest članova koji se odnose na sledeća pitanja: pravo radnika na informisanje i konsultacije u preduzeću, pravo na kolektivno pregovaranje i delovanje, pravo na pristup uslugama posredovanja u zapošljavanju, zaštita u slučaju neopravdanog otkaza, pravični i pošteni uslovi rada, zabrana rada dece i zaštita mladih na radu, porodični i profesionalni život, socijalna sigurnost i socijalna pomoć, zdravstvena zaštita, pristup uslugama od opšteg ekonomskog interesa i zaštita potrošača (član 2738). Zbog ograničenog prostora, ova pitanja u analizi ostavljamo po strani.

\section{ODNOS POVELJE PREMA MEĐUNARODNOM PRAVU / \\ RELATIONSHIP OF THE CHARTER TO INTERNATIONAL LAW}

Za analizu odnosa Povelje prema pravu na (zdravu) životnu sredinu trebalo bi voditi računa i o pitanju odnosa Povelje prema međunarodnom pravu, o čemu su već date izvesne naznake. Ovome doprinosi nekoliko razloga, a ključnim bi se mogla smatrati činjenica da je EU članica određenih me- đunarodnih ugovora, među kojima su i neki koji upućuju na pravo na (zdravu) životnu sredinu.

Svoj odnos prema međunarodnom pravu Povelja je regulisala tako što se na nekoliko mesta eksplicitno određuje prema ovom pitanju. Već u alineji 5. preambule zapisano je da ... „uz uvažavanje ovlašćenja i zadataka Unije i načela supsidijarnosti, ova povelja ponovo potvrđuje prava koja proističu naročito iz ustavnih tradicija i međunarodnih obaveza koje su zajedničke za države članice, iz Evropske konvencije za zaštitu ljudskih prava i osnovnih sloboda, socijalnih povelja koje su usvojile Unija i Savet Evrope, kao i sudske prakse Suda pravde Evropske unije i Evropskog suda za ljudska prava“. $\mathrm{Na}$ Konvenciju za zaštitu ljudskih prava i osnovnih sloboda ukazuje se i u članu 52. st. 3. gde je zapisano sledeće: „Ukoliko ova povelja sadrži prava koja odgovaraju pravima zajemčenim Konvencijom za zaštitu ljudskih prava i osnovnih sloboda, značenje i obim tih prava su istovetni onima utvrđenim tom konvencijom. Ova odredba ne sprečava da se pravom Unije predvidi šira zaštita“. Propisano je i to da se nijedna odredba ove povelje ne može tumačiti kao „ograničavanje ili negativno uticanje na ljudska prava i osnovne slobode koji su, u okviru odgovarajućih oblasti primene, priznati pravom Unije i međunarodnim pravom, međunarodnim sporazumima čije su ugovorne strane Unija ili sve države članice, uključujući Evropsku konvenciju za zaštitu ljudskih prava i osnovnih sloboda, kao i ustavima država članica" (čl. 53). U tom smislu Krisch (2008) podseća da se evolucija evropskog režima ljudskih prava često opisuje kao razvoj integralnog poretka ustanovljenog Evropskom konvencijom o ljudskim pravima. Marin-Duran i dr. (2013, p. 7) naglašavaju da, za razliku od drugih odredbi Povelje, u slučaju člana 37. pisci Povelje nisu crpili inspiraciju iz relevantnih ugovora iz sistema UN, naročito Arhuske konvencije u vezi s proceduralnim pravima zaštite životne sredine, niti sudske prakse Evropskog suda za ljudska prava koja je postupno razvila „ekološku“ dimenziju određenih prava zaštićenih Evropskom konvencijom o ljudskim pravim. Ovo, bez obzira na status EU u Evropskoj konvenciji o ljudskim pravima (Krstić, i dr, 2016). Ipak, treba imati u vidu da u dokumentima Saveta Evrope u oblasti ljudskih prava pravo na (adekvatnu) životnu sredinu nije eksplicitno formulisano kao ljudsko pravo. Međutim, čitav niz ljudskih prava koje je Savet Evrope utvrdio u svojim dokumentima, i o čijem ostvarivanju se stara, ima implikacije i direktne veze sa pravom na (zdravu) životnu sredinu. Kao što je poznato Savet Evrope je u ovoj oblasti doneo veći broj konvencija. Deo njih se odnosi na oblast građanskih i političkih prava. Najveći značaj ima Konvencija o zaštiti ljudskih pra- 
va i osnovnih sloboda (1950) sa jedanaest protokola, iako u detaljnijoj analizi ne bi trebalo ignorisati ni druge međunarodne ugovore zaključene u okviru ove ove organizacije. Tome bi trebalo dodati i aktivnosti Evropskog suda za ljudska prava koji se u svojim dosadašnjim aktivnostima bavio i pitanjima koja su neposredno relevantna za oblast životne sredine. Zbog veze koja je Poveljom uspostavljena sa Evropskom konvencijom za zaštitu ljudskih prava i osnovnih sloboda (na osnovu člana 52. stav 3), pitanje odnosa između Povelje i Konvencije trebalo bi detaljnije razmotriti (Brittain, 2015, Emmert i dr, 2017). Pri tom je neosporno da bi trebalo imati u vidu nekoliko posebnih prava ustanovljenih ovim međunarodnim ugovorom (Gentimir, 2020). To uključuje, ali se ne ograničiva na pravo na život (član 2. Povelje), pravo na poštovanje privatnog i porodičnog života (član 7. Povelje), pravo na vlasništvo (član 17. Povelje), sloboda informisanja (član 11. Povelje). U širem smisli za ostvarivanje prava u oblasti životne sredine mogu biti relevantni i član 43. Povelje (koji se odnosi na slučajeve lošeg upravljanja institucijama ili telima Unije), član 44. (pravo na podnošenje peticija Evropskom parlamentu), itd.

\section{Članstvo EU u međunarodnim ugovorima $u$ oblasti životne sredine i pravo na (zdravu) životnu sredinu / \\ EU membership in international environmental agreements and the right to a (healthy) environment}

Lista međunarodnih multilateralnih ugovora $u$ oblasti životne sredine u kojima je EU članica obuhvata ukupno 29 međunarodnih ugovora različitog karaktera (globalnih, regionalnih, subregionalnih) i sa različitim predmetima regulisanja (https://ec. europa.eu) Najveći broj pripada međunarodnim ugovorima kojima se uređuje zaštita prirode i biodiverziteta, zatim upravljanje vodama, civilna zaštita i akcidenti, klimatske promene i oštećenje ozonskog omotača, itd. Pregled tekstova dela spomenutih međunarodnih ugovora otkriva da relativno mali broj njih ima za svoj eksplicitno formulisan cilj zaštitu prava na zdravu životnu sredinu. Otuda, ostaje da se odredbe o pravu na (zdravu) životnu sredinu traže u delovima međunarodnih ugovora u kojima se upućuje na druge dokumente sa kojima se međunarodni ugovor nalazi u vezi a u kojima se govori o pravu na (zdravu) životnu sredinu. $U$ širem smislu (i u detaljnijoj analizi) to bi značilo i obavezu sagledavanja ciljeva pojedinih međunarodnih ugovora, uključujući i konkretne prava i obaveze.

Na primer, Okvirna Konvencija UN o promeni klime ne sadrži posebno upućivanje na pravo na (zdravu) životnu sredinu. Međutim, ovaj međunarodni ugovor se poziva na odgovarajuće odredbe Dek- laracije Konferencije Ujedinjenih nacija o čovekovoj životnoj sredini usvojene u Stokholmu, 16. juna 1972. godine, (Al. 9. Preambule) čiji prvi princip glasi: „Čovek ima osnovno pravo na slobodu, jednakost i primerene uslove života, u životnoj sredini takvog kvaliteta da dopušta dostojanstven život i blagostanje, te snosi svečanu odgovornost za zaštitu i poboljšanje životne sredine za sadašnje i buduće generacije" (UN, 1973, p. 4). Bečka konvencija o zaštiti ozonskog omotača, kao opštu obavezu strana ugovornica, proklamuje preduzimanje odgovarajućih mera „radi zaštite ljudskog zdravlja i životne okoline od štetnih posledica do kojih dolazi ili može doći od aktivnosti čoveka koje modifikuju ili verovatno mogu da modifikuju ozonski omotač" (čl. 2). Bazelska konvencija o kontroli prekograničnog kretanja opasnih otpada i njihovom odlaganju (1989) u prva četiri stava preambule direktno ukazuju na to da konvencija polazi od rizika koji postoji po ljudsko zdravlje i životnu sredinu a koji nastaje usled postojanja opasnih i drugih otpada i njihovog prekograničnog kretanja. Konvencija o borbi protiv dezertifikacije, u zemljama sa teškom sušom i/ili dezertifikacijom, posebno u Africi, ne spominje pravo na (zdravu) životnu sredinu. Istovremeno, ovaj ugovor se u preambuli poziva na Rio deklaraciju o zaštiti životne sredine i razvoju i njeno Načelo 2 u kojem se kaže „da u skladu sa Poveljom Ujedinjenih nacija i načelima međunarodnog prava, države imaju suvereno pravo na korišćenje vlastitih prirodnih resursa u skladu sa svojim vlastitim politikama zaštite životne sredine i razvoja, i odgovornost da osiguraju kako aktivnosti u okviru njihove nadležnosti ili kontrole ne bi izazvalo štete po životnu sredinu i drugih država ili područja izvan granica nacionalne nadležnosti“" (Alineja 15. Preambule). Cilj Stokholmske konvencije o dugotrajnim organskim zagađivačima (2001) takođe je definisan u članu 1. kao "zaštita ljudskog zdravlja i okoline“.

Slična je situacija i sa međunarodnim ugovorima zaključenim u okviru Ekonomske komisije UN za Evropu. Konvencija o prekograničnim efektima industrijskih udesa (1992) posebno štiti „ljude i životnu sredinu" (čl.1.ei, čl.3). Konvencija o zaštiti i korišćenju prekograničnih vodotoka i međunarodnih jezera pri definisanju štetnih efekata na životnu sredinu posebno spominje: efekat na zdravlje lli bezbednost čoveka, flore, faune, zemljišta, vazduha, vode, klime, pejzaža, istorijskih spomenika I drugih građevina ili interakciju ovih faktora. Konvencija o prekograničnom zagađivanju vazduha na velikim udaljenostima ne definiše pravo čoveka na zdravu životnu sredinu ali pri definiciji izraza "zagađivanje vazduha" ukazuje na vezu koja postoji između zagađivanja vazduha kao procesa unošenja u atmosferu materija 
ili energije sa štetnim delovanjem koje mogu dovesti u opasnost zdravlje čoveka I naneti štetu biološkim resursima, ekosistemima, materijalnim dobrima, itd. (čl.1). Konvencija o proceni uticaja na životnu sredinu u prekograničnom kontekstu takođe ne formuliše pravo na zdravu životnu sredinu već je izričiti predmet zaštite „„̌ivotna sredina” kao takva. Istina, kada se definiše pojam „uticaja” onda se se govori o svakom efektu koji je prouzrokovan određenom aktivnošću I to na životnu sredinu, uključujući I ljudsko zdravlje I bezbednost, floru, fuanu, tlo, vazduh, kli$\mathrm{mu}$, predele, istorijske spomenike itd.

Ipak, jedan međunarodni ugovor iz ove grupe regionalnih međunarodnih ugovora eksplicitno propisuje svoju vezu sa pravom na (zdravu) životnu sredinu. Konvencija o dostupnosti informacija, učešću javnosti u donošenju odluka i pravu na pravnu zaštitu u pitanjima životne sredine u članu 1. jasno formuliše kao svoj cilj „davanje doprinosa zaštiti prava svakog pojedinca sadašnjih i budućih generacija na život u životnoj sredini adekvatnoj njegovom zdravlju i blagostanju“, zbog čega strane ugovornice "garantuju pravo na dostupnost informacija, učešće javnosti u donošenju odluka i pravo na pravnu zaštitu u pitanjima životne sredine, u skladu sa odredbama ove konvencije“. Širi značaj ovog međunarodnog ugovora proističe iz činjenice da bi moglo reći da su najkonkretniji dometi u preciziranju kriterijuma demokratizacije politike u oblasti životne sredine utvrđeni upravo ovim međunarodnim ugovorom (Todić, 2018, 254).

\section{PRAVO NA (ZDRAVU) ŽIVOTNU SREDINU I USTAVI POJEDINIH DRŽAVA ČLANICA EU / THE RIGHT TO A (HEALTHY) ENVIRONMENT AND CONSTITUTIONS OF THE EU MEMBER STATES}

Na relevantnost „ustavnih tradicija“ država članica EU Povelja upućuje već u Preambuli (al. 5). Povelju i Evropsku konvenciju o ljudskim pravima, u kombinaciji s nacionalnim ustavima, Jizeng (2016, p. 38) naziva "konsolidovanom zaštitom osnovnih prava na više nivoa". U tom smislu, ako se pogledaju ustavni tekstovi odmah se uočava da se odredbe o životnoj sredini mogu pronaći u njihovim različitim delovima svih država članica EU1. Pravo na (zdravu) životnu sredinu u ustavima država članica EU regulisano je na različit način, iako se mogu uočiti izvesne zajedničke karakteristike. Tako, na primer, Ustav Češke Republike (1993, sa amandmanima) u članu 44. propisuje da „svako ima pravo na povoljnu („favourable“) životnu sredinu“ (čl. 44), kao i pravo na „pravovremene i potpune informacije o stanju životne sredine te o

\footnotetext{
${ }^{1}$ Za osnovu ovog dela članka poslužio je tekst (Todić, 2000). Za
} šire informacije koje se tiču ustavnih odredaba o životnoj sredini uzrocima i posledicama stanja životne sredine" (čl. 45). Istovremeno u članu 7. se proklamuje da država vodi računa (stara se) o mudrom korišćenju prirodnih resursa i zaštiti njenih prirodnih bogatstava. I nekoliko odredbi Ustava Poljske (1997) se odnose na životnu sredinu. Najpre, u članu 5. se proklamije da će Republika Poljska štiti nezavisnost i integritet teritorije te osigurati slobode i prava osoba i građana, sigurnost građana, čuvati nacionalnu baštinu i obezbediti zaštitu prirodnog okruženja u skladu $s$ načelima održivog razvoja. Organi javne vlasti su u obavezi da „spreče negativne posledice po zdravlje usled degradacije životne sredine (čl. 68. st. 4). Oni su u obavezi da sprovode politiku koja će obezbediti „ekološku bezbednost sadašnjih i budućih generacija“ (čl. 74. st. 1), a svako ima pravo da bude obavešten o kvalitetu životne sredine i njegovoj zaštiti (st. 3). Svi imaju obavezu da se staraju o kvalitetu životne sredine i odgovorni su za izazivanje njegove degradacije, a pravila odgovornosti biće propisana zakonom (čl. 86).

Mađarski ustav (1949. sa amandmanima iz 1997) sadrži u članu 18. eksplicitnu odredbu o tome da će Mađarska Republika primenjivati „individualno pravo na zdravu životnu sredinu". Pored ove odredbe koja je sadržana u Glavi I (Opšte odredbe), član 70E (Glava XII) takođe sadrži odredbu koja se odnosi na životnu sredinu posredstvom prava na "najviši mogući nivo fizičkog i mentalnog zdravlja“. Ovo pravo Republika Mađarska će realizovati kroz institucije sigurnosti na radu, zdravstvene nege, kroz organizacije za medicinsko zbrinjavanje, kao i putem zaštite gradske i prirodne sredine. I ustav Rumunije (1991, sa izmenama iz 2003) priznaje „pravo svake osobe na zdravu, dobro očuvanu i uravnoteženu životnu sredinu (čl. 35 , st. 1), a država je obavezna da „obezbedi zakonodavni okvir za ostvarivanje tog prava. Fizička i pravna lica su dužna da „štite i unapređuju životnu sredinu“ (st. 3). I bugarski ustav (1991) članom 55 (II glava „osnovna prava i obaveze građana") utvrđuje pravo građana Bugarske da imaju „zdravu i povoljnu životnu sredinu koja odgovara utvrđenim standardima i normama", u skladu sa čim građani štite životnu sredinu. Art. 15. Republika Bugarska osigurava zaštitu i reprodukciju životne sredine, očuvanje žive prirode u svoj njezinoj raznolikosti i razumno korištenje prirodnih i drugih bogatstava zemlje (čl. 15).

Hrvatska je svoj odnos prema životnoj sredini regulisala članom 69. Ustava (1990, sa kasnijim izmenama) tako što je propisano da „svako ima pravo na zdrav život", a država osigurava uslove za zdravu

sačinjene su na osnovu ustavnih tekstova objavljenih na sajtu Agencije EU za fundamentalna prava: https://fra.europa.eu/ 
životnu sredinu. U tom smislu „svako je dužan, u sklopu svojih ovlasti i djelatnosti, osobitu skrb posvećivati zaštiti zdravlja ljudi, prirode i ljudskog okoliša“. Životna sredina se još spominje i u članu 3, 50. i 134. Ustava. Ustav Slovenije (1991) propisuje u članu 72. da svako ima pravo na zdravu životnu sredinu, u skladu sa zakonom, a država unapređuje zdravu životnu sredinu. Radi toga će se zakonski urediti uslovi i način obavljanja ekonomskih i drugih aktivnosti. Zakonom će se utvrditi pod kojim uslovima i u kojoj meri je osoba koja je oštetila životnu sredinu dužna da da odštetu, kao i zaštita životinja od okrutnosti.

Austrijski savezni ustavni zakon o održivosti, zaštiti životinja, zaštiti životne sredine, voda, bezbednosti hrane i istraživanjima (2013, sa izmenama iz 2019) propisuje da je Republika Austrija (savezna vlada, savezne pokrajine i opštine) „posvećena“ načelu održivosti u korišćenju prirodnih resursa kako bi se osiguralo da i buduće generacije imaju optimalan kvalitet života. Pored toga, Republika Austrija posvećena je zaštiti životinja i „sveobuhvatnoj zaštiti životne sredine“. Ustav Španije iz 1992. godine u članu 45. sadrži odredbe o životnoj sredini. Svakome se daje pravo da uživa u životnoj sredini „pogodnoj za ravoj pojedinaca" ali svako ima i dužnost da je štiti. Javne vlasti će se angažovati u pitanjima racionalnog korišćenja svih prirodnih resursa za svrhe zaštite i unapređivanja kvaliteta života i zaštite i obnavljanja životne sredine polazeći pri tom od „nužne kolektivne solidarnosti".

Portugalski ustav iz 1976. sa amandmanima iz 1997. godine u članu 9., kojim se utvrđuju „osnovne odgovornosti države“, utvrđuje između ostalog, da je osnovna dužnost države da unapređuje blagostanje i kvalitet života ljudi i jednakosti između Portugalaca u njihovom uživanju ekonomskih, socijalnih, kulturnih i prava životne sredine. Najznačajnije i neobično razrađene odredbe o životnoj sredini sadržane su u članu 66. koji je naslovljen kao „životna sredina i kvalitet života“. Ovaj član sadrži odredbu po kojoj svako ima pravo na „zdravu i ekološki uravnoteženu životnu sredinu“, ali i dužnost da je štiti (st. 1). Kako bi se obezbedilo uživanje prava na životnu sredinu, u nastavku ove odredbe se propisuju nadležnosti odgovarajućih organa.

Ustav Grčke (1975), polazeći od specifičnosti prirodnih I kulturnih okolnosti u ovoj zemlji, u članu 24 (u delu koji se odnosi na ,individualna I socijalna prava") sadrži vrlo dugu odredbu o zaštiti životne sredine $i$ to posebno šuma, gradova, planina $i$ istorijskih lokaliteta. Ustav Finske (1999, sa amandmanima iz 2018) u članu 20, koji je naslovljen sa "odgovornost za životnu sredinu“, propisuje da su priroda i njena biološka raznovrsnost, životna sre- dina i nacionalna baština odgovornost svih, a da javna vlast garantuje svima pravo na zdravu životnu sredinu i mogućnost da utiče na odluke koje se tiču njegove vlastite životne sredine. Ustav Norveške (1814 sa amandmanima koji su u međuvremenu doneti), sadrži odredbu kojom se utvrđuje da „svaka osoba ima pravo na životnu sredinu koja je korisna (pogodna) za zdravlje I prirodni ambijent čija je produktivnost i raznolikost očuvana".

Luksemburški ustav (1868, sa amadmanima) propisuje da država garantuje zaštitu životne sredine (ljudske i kulturne), te radi na uspostavljanju trajne ravnoteže između očuvanja prirode, posebno njene sposobnosti obnove i zadovoljenja potreba sadašnjih i budućih generacija (čl. 11bis). Ustav Belgije (1970. sa amandmanima do 1994. godine) garantuje u članu 23 pravo na "ljudsko dostojanstvo”, dok je pravo na korišćenje (uživanje) „zaštite zdrave životne sredine" propisano članom 134 (tačka 3 i 4), koji se odnosi na ekonomska, socijalna i kulturna prava. Pored ovog prava u grupi prava vezanih za ljudsko dostojanstvo je i pravo na socijalnu sigurnost, zdravstvenu negu i socijalnu, medicinsku i pravnu pomoć, itd.

Ustav Republike Litvanije (1992) u članu 53. propisuje obaveze države i svih osoba da zaštite životnu sredinu od štetnih uticaja. Ovo se, prema članu 54. odnosi na zaštitu prirodne životne sredine, faune i flore, pojedinačnih objekata prirode i područja posebne namene, itd. Zabranjuje se uništavanje zemljišta, zagađenje vode i vazduha, degradacija životne sredine, itd. Nešto određeniju odredbu o pravu na povoljnu životnu sredinu sadrži ustav Letonije (1993, sa izmenama) koji u članu 115. propisuje da će država štititi pravo svakoga na život u dobronamernoj (povoljnoj) životnoj sredini davanjem informacija o uslovima životne sredine i unapređenjem očuvanja i poboljšanja. Estonskim ustavom (1992, sa kasnijim izmenama) je propisano da je svako dužan čuvati „ljudsku i prirodnu životnu sredinu“ i nadoknaditi štetu koju nanese životnoj sredini (čl. 53).

Nema posebne odredbe o pravu na (zdravu) životnu sredinu u ustavu Italije (1947), iako je članom 9. propisano da Republika unapređuje razvoj kulture i naučno-tehnoloških istraživanja i štiti prirodno okruženje i istorijske i umetničku baštinu. Obavljanje poslova zaštite životne sredine, ekosistema i kulturne baštine u nadležnosti je države i regiona (čl. 117). Osnovni zakon Nemačke (1949. sa izmenama) propisuje da će država, s obzirom na svoju odgovornost prema budućim generacijama, zakonom štiti „prirodne temelje života i životinje" (čl. 20a). U slučaju Francuske Ustav iz 1958. godine propisuje da svaka osoba ima pravo da živi u „uravnoteženoj životnoj 
sredini uz dužno poštovanje zdravlja“ (čl. 1), a javne politike unapređuju održivi razvoj (čl. 6).

\section{ZAKLJUČAK / CONCLUSION}

Povelja EU o osnovnim pravima sadrži posebnu odredbu o životnoj sredini, ali je sadržaj norme iz člana 37. formulisan tako da se ona ne može tumačiti kao garant prava na (zdravu) životnu sredinu. Njome su definisani opšti ciljevi i obaveze nadležnih subjekata. Međutim, u analizi odnosa između člana 37. i drugih relevantnih odredbi Povelje, kao i odnosa Povelje prema međunarodnim ugovorima $u$ oblasti životne sredine, uočavaju se elementi koji pitanja prava na (zdravu) životnu sredinu aktuelizuju i otvaraju na specifičan način. Indikaciju u pravcu priznavanja ovog prava sadrže odredbe Povelje kojima se propisuje odnos prema međunarodnim ugovorima, a posebno prema Evropskoj konvenciji o osnovnim pravima i slobodama, kao i sadržaj ustavnih odredbi država članica EU.

Analiza pokazuje i to da relativno mali broj međunarodnih ugovora u oblasti životne sredine ima za svoj eksplicitno formulisan cilj zaštitu prava na zdravu životnu sredinu, a najjasniju odredbu u tom pravcu sadrži Arhuska konvencija čiji su član EU i države članice ove organizacije. Međutim, skoro svi analizirani međunarodni ugovori formulišu eksplicitne veze između „zdravlja“ i životne sredine, bilo kroz svoje ciljeve ili u delu koji se odnosi na konkretne obaveze i prava. Istovremeno, ustavne odredbe država članica EU koje se odnose na životnu sredinu, pokazuju različit pristup pitanju odnosa prema životnoj sredini. Jedan broj ustavnih odredbi eksplicitno priznaje pravo na (zdravu) životnu sredinu, dok jedan broj sadrži različite odredbe o životnoj sredini kroz propisivanje obaveza nadležnih organa.

\section{Zahvalnica / Acknowledgments}

Rad je nastao u okviru naučnoistraživačkog projekta „Srbija i izazovi u međunarodnim odnosima 2021. godine", koji finansira Ministarstvo prosvete, nauke i tehnološkog razvoja Republike Srbije, a realizuje Institut za međunarodnu politiku i privredu tokom 2021. godine.

\section{LITERATURA / REFERENCES}

[1] Bell, D. (2013). Climate change and human rights, WIREs Climate Change, 4(3), 159-170.

[2] Borras, S. (2016). New Transitions from Human Rights to the Environment to the Rights of Nature, Transnational Environmental Law, 5(1), 113-143.

[3] Brittain, S. (2015). The Relationship Between the EU Charter of Fundamental Rights and the European Convention on Human Rights: an Origin- alist Analysis, European Constitutional Law Review, 11(3), 482-511.

[4] Dawson, M. (2020). Fundamental Rights in European Union Policy-making: The Effects and Advantages of Institutional Diversity, Human Rights Law Review, 20, 50-73.

[5] Dawson, M., Lynskey, O., Muir, E. (2019). What is the Added Value of the Concept of the "Essence" of EU Fundamental Rights? German Law Journal, 20 (6), 763-778.

[6] De Sadeleer, N. (2012). Enforcing EUCHR Principles and Fundamental Rights in Environmental Cases, Nordic Journal of International Law, 81 (1), 39-74.

[7] Dogaru, L. (2014). Preserving The Right To A Healthy Environment: European Jurisprudence, Procedia - Social and Behavioral Sciences, 141, 1346-1352

[8] Đorđević, S. (2011). Pravni status Povelje o osnovnim pravima Evropske unije, Zbornik radova Pravnog fakulteta u Nišu, 58, 219-234.

[9] Emmert, F., Carney, C.P. (2017). The European Union Charter of Fundamental Rights VS. The Council of Europe Convention on Human Rights and Fundamental Freedoms - A Comparison, Fordham International Law Journal, 40(4), 10471174.

[10] Etinski, R. (2008). Proces promocije ljudskih prava u Evropskoj uniji, Zbornik radova Pravnog fakulteta u Novom Sadu, 1-2, 115-131.

[11] EU. (2007). Charter of Fundamental Rights of the European Union, Official Journal of the European Union C 303/17 - 14.12.2007.

[12] Feliziani, C. (2012). The Duty of Member States to Guarantee the Right to aHealthy Environment: A Consideration of European Commission v Italy (C-297/08), Journal of Environmental Law, 24 (3), p. 543

[13] Gentimir, A. (2020). Environmental Protection as Fundamental Right Guaranteed to the European Level, PESD, 14(2), 121-130.

[14] Giorgetta, S. (2002). The Right to a Healthy Environment, Human Rights and Sustainable Development, International Environmental Agreements: Politics, Law and Economics, 2(2),173-194.

[15] https://ec.europa.eu/environment/international_is sues/agreements_en.htm (11.09.2021).

[16] https://fra.europa.eu/en/eu-charter/article/37environmental-protection?page $=2 \#$ TabNational (11.09.2021).

[17] Jizeng, F. (2016). Convergence, Compatibility or Decoration: The Luxembourg Court's References to Strasbourg Case Law in its Final Judgments, 
Pécs Journal of International and European Law, 2, 38-67.

[18] Klinger, R. (2021). Time for an Update of the EU Charter of Fundamental Rights: Why the Initiative "Everyone" Comes at the Right Time, Völkerrechtsblog, 14.04.2021, doi:10.17176/20210414100923-0.

[19] Krisch, N. (2008). The Open Architecture of European Human Rights Law, The Modern Law Review, 71 (2), 183-216.

[20] Krstić, I., Čučković, B. (2016). Pristupanje Evropske unije Evropskoj konvenciji o ljudskim pravima kao vid unapređenja zaštite ljudskih prava u Evropi, Anali Pravnog fakulteta u Beogradu, 2, 49-78.

[21] Magalhães, M. (2018). The Improvement of Article 37 of the EU Charter of Fundamental Rights - A Choice Between an Empty Shell and a Test Tube? In: J. Jendroska \& M. Bar (Eds.), Procedural Environmental Rights: Principle $X$ in Theory and Practice (pp. 97-118). Intersentia.

[22] Marin-Duran, G., Morgera, E (2013). Commentary on Article 37 of the EU Charter of Fundamental Rights: Environmental Protection, Europa Working Papers, no. 2013/02, Europa Working Paper. University of Edinburgh School of Law, p. 7.

[23] MEI. (2021). Povelja Evropske unije o osnovnim pravima (prevod na srpski jezik), Ministarstvo za evropske integracije, https://www.mei.gov.rs/upload /documents/eu_dokumenta/povelja_osnovna_ prava_jul_20.pdf. (11.09.2021).

[24] Misonne, D. (2021). The emergence of a right to clean air: Transforming European Union law through litigation and citizen science, Review of European, Comparative \& International Environmental Law, 30(1), pp. 34-45.

[25] Todić, D. (2018). Ujedinjene nacije, međunarodni ugovori i životna sredina, Institut za međunarodnu politiku i privredu, Beograd, str. 254.

[26] Todić, D. (2000). Odredbe o zaštiti životne sredine u Ustavu SR Jugoslavije i ustavima drugih država, Strani pravni život, 1-3, 55-80.

[27] UN. (1973). Report of the United Nations Conference on the Human Environment, Stockholm, 516 June 1972, United Nations, New York, p. 4.

[28] UN. (2019). Report of the Special Rapporteur on the issue of human rights obligations relating to the enjoyment of a safe, clean, healthy and sustainable environment. A/74/161, 15 July 2019.

[29] Vučić, M. (2017). Ljudsko pravo na vodu - između plemenite ideje i surove realnosti. Pravni život, 66, 515-528.

[30] Vukasović, V., Todić, D. (2021). Environmental Law in Serbia, Kluwer Law International B.V, The Netherlands, p. 146. 